\title{
Tanshinone IIA down-regulates the protein expression of ErbB-2 and up-regulates TNF- $\alpha$ in colon cancer cells in vitro and in vivo
}

\author{
CHIN-CHENG SU ${ }^{1,2}$ and YI-HSIANG LIN ${ }^{2}$ \\ ${ }^{1}$ Division of General Surgery, Buddhist Tzu Chi General Hospital, No. 707, Sec. 3 , \\ Chung Yang Road, Hualien City 970; ${ }^{2}$ Tzu Chi University, No. 701, Sec. 3 , \\ Chung Yang Road, Hualien City 970, Taiwan, R.O.C.
}

Received August 19, 2008; Accepted October 2, 2008

DOI: 10.3892/ijmm_00000094

\begin{abstract}
Tanshinone IIA (Tan-IIA) was isolated from Salviae Miltiorrhizae Radix. Our previous studies showed that Tan-IIA induced apoptosis in human colon cancer colo 205 cells, but the molecular mechanisms of the effect of Tan-IIA on human colon cancer were not clearly elucidated. The protein expression of ErbB-2 was up-regulated and activated in human and experimental colon cancers. In the present study, the effects of Tan-IIA on the protein expression of ErbB-2 in colo 205 cells were investigated. In vitro, colo 205 cells were treated with various concentrations of Tan-IIA (1, 2 and $5 \mu \mathrm{g}$ / $\mathrm{ml}$ ) for $24 \mathrm{~h}$, and the protein expression of TNF- $\alpha$, ErbB-2 and caspase- 3 was assayed by Western blotting. For the in vivo studies, male SCID mice were xenografted with colo 205 cells, and from day 10, Tan IIA (20 mg/kg/day, dissolved in corn oil) was administered by oral feeding for 30 days. As a control, mice with xenografted tumors were separately treated with corn oil ( $0.1 \mathrm{ml} / 10 \mathrm{~g}$ body weight). Expression of TNF- $\alpha$, ErbB-2 and caspase-3 proteins was measured by Western blot analysis. Our results showed that Tan-IIA down-regulated the protein expression of ErbB-2 and up-regulated TNF- $\alpha$ and caspase- 3 in colo 205 cells in vitro. In a colo 205 xenograft model, treatment with Tan-IIA caused up-regulation of TNF- $\alpha$, caspase- 3 and down-regulation of ErbB-2 protein expression as compared to the controls. Based on these observations, one possible molecular mechanisms by which Tan-IIA inhibits the proliferation of colo 205 cells is through the downregulation of ErbB-2 protein expression and the upregulation of the protein expression of TNF- $\alpha$ and caspase- 3 .
\end{abstract}

Correspondence to: Dr Chin-Cheng Su, Division of General Surgery, Buddhist Tzu Chi General Hospital, No. 707, Sec. 3, Chung-Yang Road, Hualien City 970, Taiwan, R.O.C.

E-mail: succ.maeva@msa.hinet.net

Key words: tanshinone IIA, colo 205 cells, ErbB-2, tumor necrosis factor $\alpha$

\section{Introduction}

Danshen (Salviae miltiorrhizae Radix) is widely prescribed in traditional Chinese medicine to treat cardiovascular diseases and dysmenorrhea $(1,2)$. Tanshinone IIA (Tan-IIA), an extract from Danshen $(3,4)$, possesses anti-inflammatory activities $(5,6)$, anti-oxidant properties (7-9) and anti-cancer activity in multiple types of human cancer cells (10-12). Our previous study showed that Tan-IIA has the ability to induce cell growth reduction and apoptosis in human colon cancer colo 205 cells, but the molecular mechanisms were not clearly elucidated. Tumor necrosis factor $\alpha$ (TNF- $\alpha$ ), a cytotoxic factor, is produced by macrophages (13). TNF receptor type 1 , a cytokine receptor, is expressed in most tissues, and can be activated by binding to TNF- $\alpha$, forming the death inducing signaling complex. This results in the recruitment of caspases and the induction of its autoproteolytic activation and subsequent cleaving of effector caspase-3 leading to cell apoptosis (14). It is well documented that ErbB-2 (erythroblastosis oncogene $\mathrm{B}$; HER-2/neu) is one of the transmembrane tyrosine kinase receptor that is overexpressed in human colorectal adenocarcinomas and serves as an independent prognostic factor (15-17). This knowledge can be applied to develop new chemotherapeutic medication which blocks the expression of ErbB-2 in colorectal cancer patients. The present study was designed to identify the effects of Tan-IIA on the protein expression of ErbB-2 in colon cancer colo 205 cells in vivo and in vitro.

\section{Materials and methods}

Chemicals and reagents. Tan-IIA (molecular formula $\mathrm{C}_{19} \mathrm{H}_{18} \mathrm{O}_{3}$, purity $>96 \%$ by HPLC) was purchased from Herbasin Co. (Shenyang, P.R. China). Aprotinin, antipain, sodium deoxycholate, leupeptin, propidium iodide (PI), sodium orthovanadate, Triton X-100, Tris- $\mathrm{HCl}$, ribonuclease- A and trypan blue were obtained from Sigma Chemical Co. (St. Louis, MO, USA). Dimethyl sulfoxide (DMSO), potassium phosphate and TE buffer were purchased from Merck Co. (Darmstadt, Germany). RPMI-1640 medium, fetal bovine serum (FBS), penicillin-streptomycin, trypsin-EDTA and 
glutamine were obtained from Gibco BRL (Grand Island, NY, USA).

Cell cultures. The human colon cancer cell line (colo 205, human colon adenocarcinoma) was obtained from the Food Industry Research and Development Institute (Hsin-chu, Taiwan, R.O.C.). The cells were placed into $75-\mathrm{cm}^{3}$ tissue culture flasks and grown at $37^{\circ} \mathrm{C}$ in a humidified atmosphere of $5 \% \mathrm{CO}_{2}$ and $95 \%$ air in RPMI-1640 medium, containing $10 \%$ heat-inactivated fetal bovine serum (FBS), $2 \%$ penicillinstreptomycin $(10,000 \mathrm{U} / \mathrm{ml}$ penicillin; $10 \mathrm{mg} / \mathrm{ml}$ streptomycin), $1 \%$ HEPES, $1 \%$ sodium pyruvate and $1 \%$ glutamine.

The effects of Tan-IIA on the protein expression of TNF- $\alpha$, ErbB-2, caspase- 3 and $\beta$-actin in colo 205 cells in vitro

Protein preparation. For protein extraction, colo 205 cells $\left(2 \times 10^{6}\right)$ were initially seeded on $10-\mathrm{cm}$ cultured dishes and treated with Tan-IIA at the concentrations of $0,1,2$ and $5 \mu \mathrm{g} /$ $\mathrm{ml}$ for $24 \mathrm{~h}$ before cells were harvested by centrifugation. Proteins were extracted as previously described (18). Briefly, cell pellets were resuspended in modified RIPA buffer (50 mM Tris-HCl, pH 7.5, $150 \mathrm{mM} \mathrm{NaCl}, 1 \%$ Nonidet p-40, $0.25 \%$ sodium deoxycholate, $1 \mathrm{mM}$ EGTA, $1 \mathrm{mM}$ DTT, $1 \mathrm{mM}$ PMSF, $1 \mathrm{mM}$ sodium orthovanadate, $1 \mathrm{mM}$ sodium fluoride, $5 \mu \mathrm{g} / \mathrm{ml}$ aprotinin, $5 \mu \mathrm{g} / \mathrm{ml}$ leupeptin and $5 \mu \mathrm{g} / \mathrm{ml}$ antipain) for $30 \mathrm{~min}$ at $4^{\circ} \mathrm{C}$. Lysates were immediately centrifuged at $13,000 \times \mathrm{g}$ for $20 \mathrm{~min}$ at $4^{\circ} \mathrm{C}$, and the supernatant was collected, aliquated (50 g/tube) and stored at $-80^{\circ} \mathrm{C}$ until assay. The extracted protein concentrations were measured using the Bradford method (19).

Western blotting. All protein samples were separated by $12 \%$ sodium dodecylsulfate polyacrylamide gel electrophoresis (SDS-PAGE) (Bio-Rad Life Science Products, Hercules, CA, USA) as previously described (18). The SDSseparated proteins were followed by equilibration in transfer buffer (50 mM Tris, pH 9.0, $40 \mathrm{mM}$ glycine, 0.375\% SDS and $20 \%$ methanol) and were transferred onto an Immobilon-P membrane (Millipore Corp., Bedford, MA, USA). The membranes were incubated with $5 \%$ nonfat dry milk in Trisbuffered saline containing $0.05 \%$ Tween-20 for $1 \mathrm{~h}$. The membranes were then washed and incubated with appropriate dilutions of specific antibodies such as TNF- $\alpha$, ErbB-2, caspase- 3 and $B$-actin (Upstate, Lake Placid, NY, USA) at $4^{\circ} \mathrm{C}$ overnight. After incubation with anti-mouse peroxidaseconjugated antibody (Santa Cruz, CA, USA), the immunoreactive bands were visualized with an enhanced chemiluminescence (ECL, Amerham Pharmacia Biotech) detection kit. The detection of $B$-actin was used as an internal control in all of the data for Western blotting.

The effects of Tan-IIA on the protein expression of TNF- $\alpha$, ErbB-2, caspase-3 and $\beta$-actin in colo 205 cell xenograft tumors. Three-week-old male nude SCID mice were xenografted with colon cancer colo 205 cells $\left(2 \times 10^{6} / 0.2 \mathrm{ml}\right)$ and maintained in a pathogen-free environment (Laboratory Animal Center of Tzu Chi University, Hualien, Taiwan, R.O.C.). From day 10, Tan IIA (20 mg/kg/day, $0.2 \mathrm{mg}$ Tan IIA dissolved in $0.1 \mathrm{ml}$ corn oil) was administered by oral feeding for 30 days ( $\mathrm{n}=5$ mice). The mice were subsequently sacrificed by $\mathrm{CO}_{2}$ inhalation. As a control, mice $(n=4)$

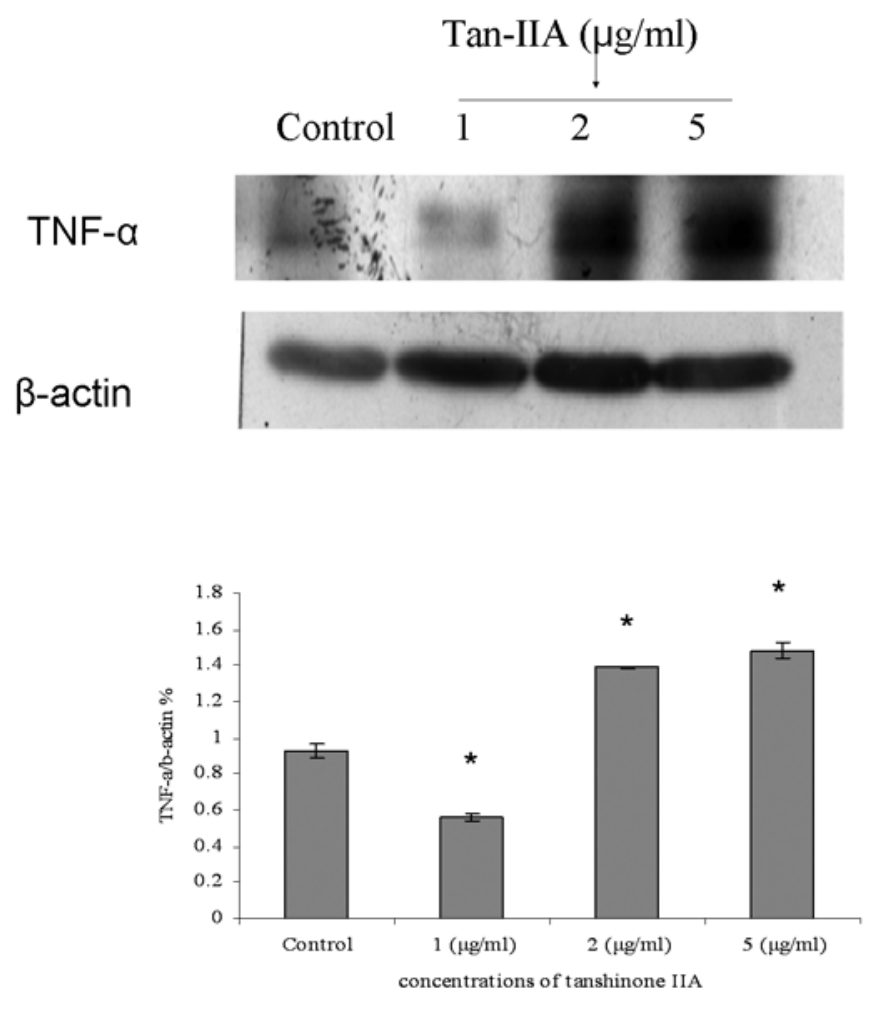

Figure 1. The protein expression of TNF- $\alpha$ in colo 205 cells treated with Tan-IIA $(1,2$ and $5 \mu \mathrm{g} / \mathrm{ml})$ for $24 \mathrm{~h}$. Tan-IIA increased the protein expression of TNF- $\alpha$ at the concentrations of 2 and $5 \mu \mathrm{g} / \mathrm{ml}$ for $24 \mathrm{~h}$. Values are expressed as the means \pm SD $(n=3)$. *Significant difference at $\mathrm{p}<0.05$ vs the respective groups without Tan-IIA treatment.

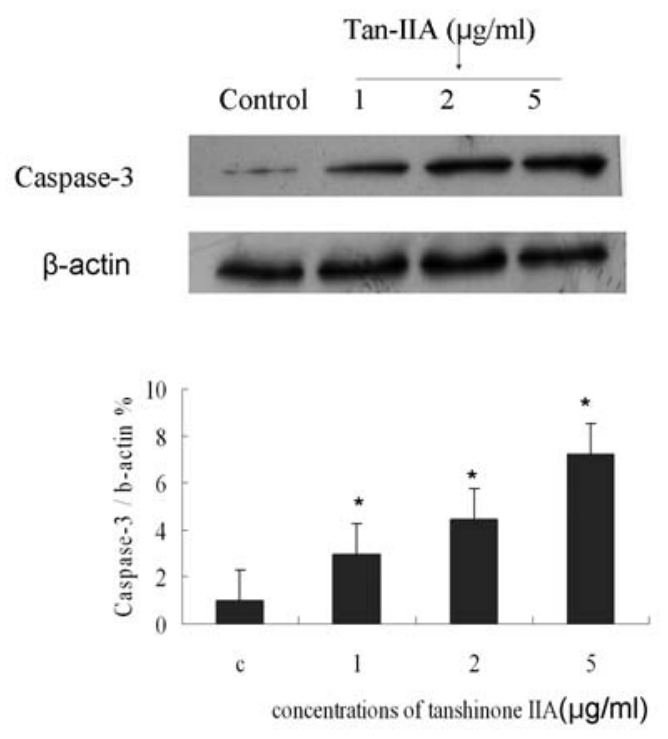

Figure 2. The protein expression of caspase- 3 in colo 205 cells treated with Tan-IIA $(1,2$ and $5 \mu \mathrm{g} / \mathrm{ml})$ for $24 \mathrm{~h}$. Tan-IIA increased the protein expression of caspase- 3 at the concentrations of 1,2 and $5 \mu \mathrm{g} / \mathrm{ml}$ for $24 \mathrm{~h}$. Values are expressed as the means \pm SD $(n=3)$. *Significant difference at $\mathrm{p}<0.05$ vs the respective groups without Tan-IIA treatment.

bearing xenografted tumors were separately treated with corn oil $(0.1 \mathrm{ml} / 10 \mathrm{~g}$ body weight). The xenograft tumors were dissected, and protein was extracted for Western blot analysis. The protein expression of TNF- $\alpha$, ErbB-2 and caspase- 3 was 

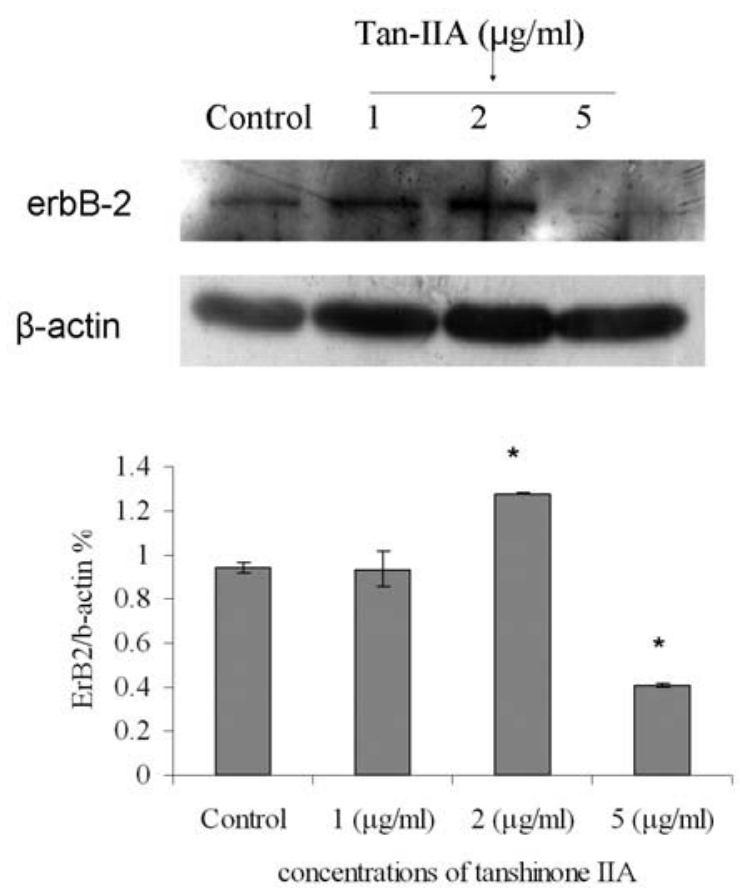

Figure 3. The protein expression of ErbB-2 in colo 205 cells treated with Tan-IIA $(1,2$ and $5 \mu \mathrm{g} / \mathrm{ml})$ for $24 \mathrm{~h}$. The protein expression of ErbB-2 in colo 205 cells was significantly decreased when treated with Tan-IIA at the concentration of $5 \mu \mathrm{g} / \mathrm{ml}$ for $24 \mathrm{~h}$. Values are expressed as the means $\pm \mathrm{SD}$ $(\mathrm{n}=3)$. *Significant difference at $\mathrm{p}<0.05 \mathrm{vs}$ the respective groups without Tan-IIA treatment.

measured by Western blotting. Immunoreactive bands were scanned and analyzed using a digital scanning densitometer (Molecular Dynamics, Sunnyvale, CA, USA).

Statistical analysis. Values are presented as the means \pm SD. The Student's t-test was used to analyze statistical significance. A p-value $<0.05$ was considered statistically significant for all tests.

\section{Results}

The effects of Tan-IIA on the protein expression of TNF- $\alpha$, ErbB-2, caspase-3 and $\beta$-actin in colo 205 cells in vitro. The colo 205 cells $\left(2 \times 10^{6} / \mathrm{ml}\right)$ were treated with various concentrations $(0,1,2$ and $5 \mu \mathrm{g} / \mathrm{ml})$ of Tan-IIA for $24 \mathrm{~h}$, and total protein was prepared and determined as described in Materials and methods. Colo 205 cells were harvested in the presence of Tan-IIA for Western blotting. The results indicated that Tan-IIA increased the expression of TNF- $\alpha$ at the concentrations of 2 and $5 \mu \mathrm{g} / \mathrm{ml}$ for $24 \mathrm{~h}$ (Fig. 1) and the expression of caspase- 3 at the concentrations of 1,2 and $5 \mu \mathrm{g} / \mathrm{ml}$ for $24 \mathrm{~h}$ (Fig. 2). The protein expression of ErbB-2 in colo 205 cells was significantly decreased when treated with Tan-IIA at the concentration of $5 \mu \mathrm{g} / \mathrm{ml}$ for $24 \mathrm{~h}$ (Fig. 3).

The effect of Tan-IIA on the protein expression of TNF- $\alpha$, ErbB-2, caspase-3 and $\beta$-actin in colo 205 xenograft tumors. SCID mice with colo 205 cell xenograft tumors were treated with Tan-IIA $(20 \mathrm{mg} / \mathrm{kg})$. The control group was treated with corn oil only. The xenograft tumors were dissected, and the proteins were extracted for Western blot analysis. Colo 205
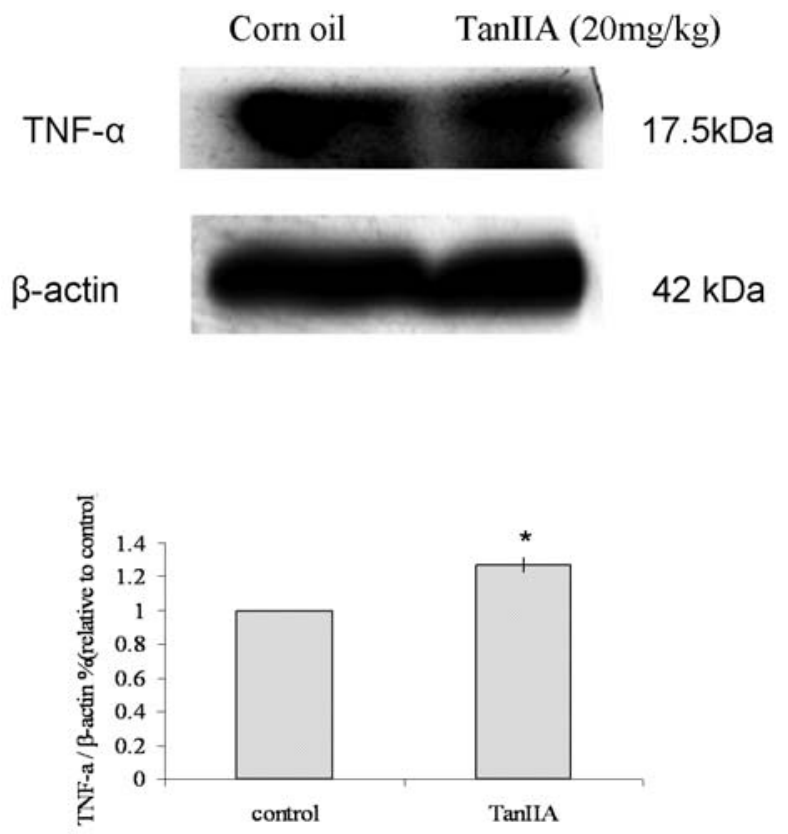

Figure 4. The effects of Tan-IIA on the protein expression of TNF- $\alpha$ in colo 205 cell xenograft tumors. Colo 205 cell xenograft tumors of SCID mice treated with Tan-IIA (20 mg/kg, p.o. x 30 days) exhibited up-regulation of the protein expression of TNF- $\alpha$ when compared to the controls. Values are expressed as the means $\pm \mathrm{SD}(\mathrm{n}=3)$. * Significant difference at $\mathrm{p}<0.05$ vs the respective groups without Tan-IIA treatment.

\section{Corn oil TanIIA $(20 \mathrm{mg} / \mathrm{kg})$}
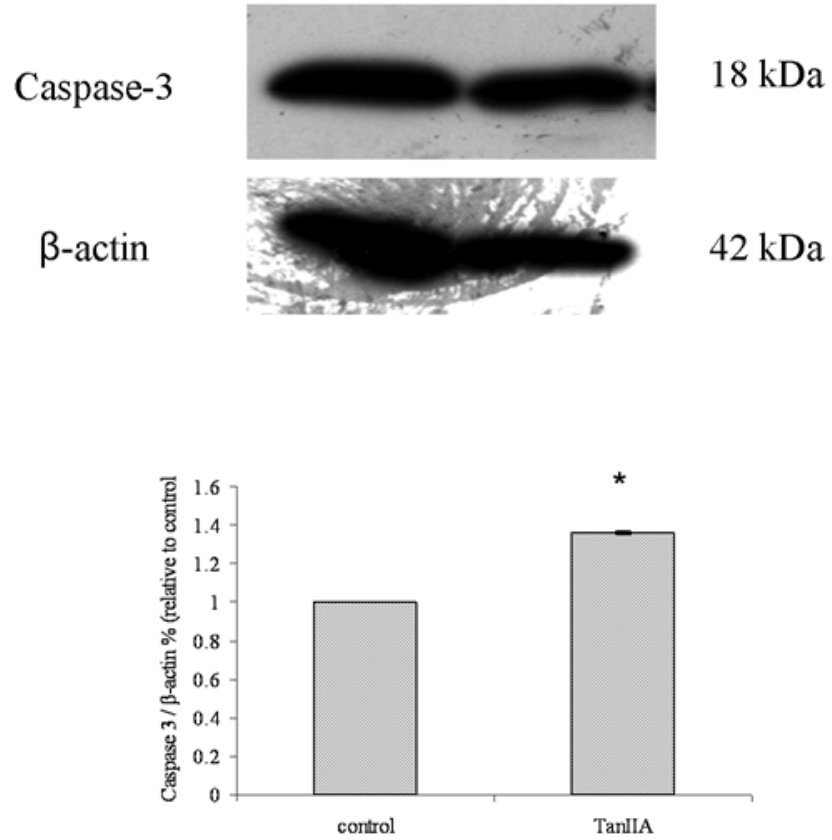

Figure 5. The effects of Tan-IIA on the protein expression of caspase- 3 in colo 205 cell xenograft tumors. Colo 205 cell xenograft tumors of SCID mice treated with Tan-IIA ( $20 \mathrm{mg} / \mathrm{kg}$, p.o. x 30 days ) exhibited up-regulation of the protein expression of caspase-3 when compared to the controls. Values are expressed as the means $\pm \mathrm{SD}(\mathrm{n}=3)$. ${ }^{*}$ Significant difference at $\mathrm{p}<0.05$ vs the respective groups without Tan-IIA treatment.

cell xenograft tumors of SCID mice treated with Tan-IIA showed up-regulation of the protein expression of TNF- $\alpha$ (Fig. 4) and caspase-3 (Fig. 5) and the down-regulation of 


\section{Corn oil TanIIA $(20 \mathrm{mg} / \mathrm{kg})$}

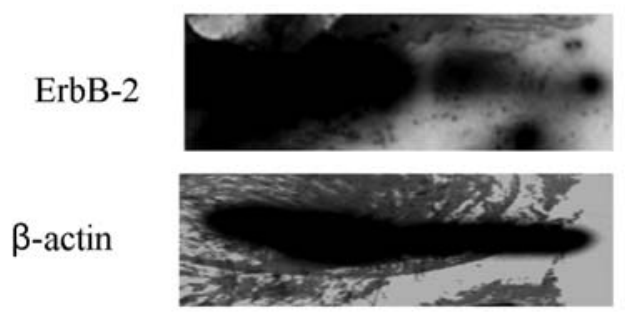

$131 \mathrm{kDa}$

$42 \mathrm{kDa}$

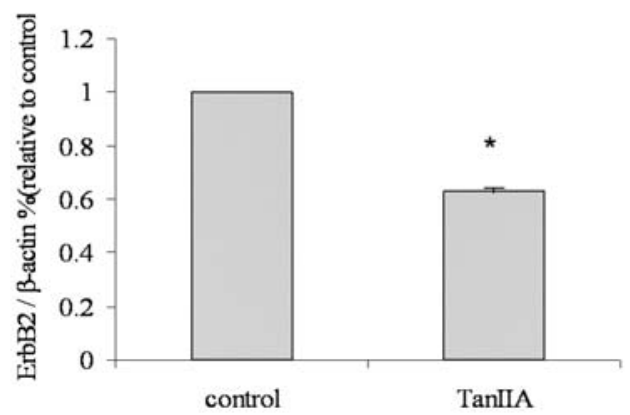

Figure 6. The effects of Tan-IIA on the protein expression of ErbB-2 in colo 205 cell xenograft tumors. Colo 205 cell xenograft tumors of SCID mice treated with Tan-IIA ( $20 \mathrm{mg} / \mathrm{kg}$, p.o. x 30 days) exhibited down-regulation of ErbB-2 protein expression when compared to the controls. Values are expressed as the means $\pm \mathrm{SD}(\mathrm{n}=3)$. ${ }^{*}$ Significant difference at $\mathrm{p}<0.05$ vs the respective groups without Tan-IIA treatment.

ErbB-2 protein expression (Fig. 6) when compared to the controls.

\section{Discussion}

Our previous studies demonstrated that Tan-IIA inhibited proliferation and induced apoptosis in human colon cancer colo 205 cells in a dose-dependent manner (20). In the present study, the results showed that Tan-IIA treatment increased the TNF- $\alpha$ and caspase- 3 levels in colo 205 cells in vivo and in vitro. It is well documented that once the TNF- $\alpha$ receptor is ligated, the receptor forms the death-inducing signaling complex, which activates the downstream caspase- 3 cascade and consequent apoptosis (14). This process is provoked by external stimuli that bind membrane receptors and ultimately activate caspases resulting in cell death (21). Therefore, Tan-IIA induces apoptosis in colon cancer cells by activating the death receptor-mediated pathways. It is well documented that inhibition of the ErbB-2 activity results in an increased propensity for apoptosis and reduced malignancy in vivo $(22,23)$. Our results demonstrate that Tan-IIA down-regulates ErbB-2 protein expression in colo 205 cells in vivo and in vitro. This is the first study to demonstrate that Tan-IIA downregulates ErbB-2 and up-regulates TNF- $\alpha$ protein expression in human colon cancer cells suggesting that Tan-IIA may have therapeutic potential for human colon cancer.

\section{Acknowledgements}

This study was supported by grant CCMP97-RD-011 from the Committee on Chinese Medicine and Pharmacy,
Department of Health, Executive Yuan, Taiwan, R.O.C.; grant TCRD96-10 from the Research Section of Buddhist Tzu Chi General Hospital, Hualien, Taiwan, R.O.C. and by The Chen-Han Foundation for Education.

\section{References}

1. Fish JM, Welchons DR, Kim YS, Lee SH, Ho WK and Antzelevitch C: Dimethyl lithospermate B, an extract of Danshen, suppresses arrhythmogenesis associated with the Brugada syndrome. Circulation 113: 1393-1400, 2006.

2. Chang PN, Mao JC, Huang SH, Ning L, Wang ZJ, On T, Duan W and Zhu YZ: Analysis of cardioprotective effects using purified Salvia miltiorrhiza extract on isolated rat hearts. J Pharmacol Sci 101: 245-249, 2006

3. Che AJ, Zhang JY, Li CH, Chen XF, Hu ZD and Chen XG: Separation and determination of active components in Radix Salviae miltiorrhizae and its medicinal preparations by nonaqueous capillary electrophoresis. J Sep Sci 27: 569-575, 2004.

4. Zhou L, Zuo Z and Chow MS: Danshen: an overview of its chemistry, pharmacology, pharmacokinetics, and clinical use. J Clin Pharmacol 45: 1345-1359, 2005.

5. Jang SI, Kim HJ, Kim YJ, Jeong SI and You YO: Tanshinone IIA inhibits LPS-induced NF-kappaB activation in RAW 264.7 cells: possible involvement of the NIK-IKK, ERK1/2, p38 and JNK pathways. Eur J Pharmacol 542: 1-7, 2006.

6. Li W, Li J, Ashok M, Wu R, Chen D, Yang L, Yang H, Tracey KJ, Wang P, Sama AE and Wang H: A cardiovascular drug rescues mice from lethal sepsis by selectively attenuating a late-acting proinflammatory mediator, high mobility group box 1 . J Immunol 78: 3856-3864, 2007.

7. Niu XL, Ichimori K, Yang X, Hirota Y, Hoshiai K, Li M and Nakazawa H: Tanshinone II-A inhibits low density lipoprotein oxidation in vitro. Free Radic Res 33: 305-312, 2000.

8. Lin R, Wang WR, Liu JT, Yang GD and Han CJ: Protective effect of tanshinone IIA on human umbilical vein endothelial cells injured by hydrogen peroxide and its mechanism. J Ethnopharmacol 108: 217-222, 2006.

9. Wang AM, Sha SH, Lesniak W and Schacht J: Tanshinone (Salviae miltiorrhizae extract) preparations attenuate aminoglycoside-induced free radical formation in vitro and ototoxicity in vivo. Antimicrob Agents Chemother 47: 1836-1841, 2003.

10. Sung HJ, Choi SM, Yoon Y and An KS: Tanshinone IIA, an ingredient of Salvia miltiorrhiza bunge, induces apoptosis in human leukemia cell lines through the activation of caspase-3. Exp Mol Med 31: 174-178, 1999.

11. Liu JJ, Lin DJ, Liu PQ, Huang M, Li XD and Huang RW: Induction of apoptosis and inhibition of cell adhesive and invasive effects by tanshinone IIA in acute promyelocytic leukemia cells in vitro. J Biomed Sci 13: 813-823, 2006.

12. Wang X, Wei Y, Yuan S, Liu G, Lu Y, Zhang J and Wang W: Potential anticancer activity of tanshinone IIA against human breast cancer. Int J Cancer 116: 799-807, 2005.

13. Carswell EA, Old LJ, Kassel RL, Green S, Fiore N and Williamson B: An endotoxin-induced serum factor that causes necrosis of tumors. Proc Natl Acad Sci USA 72: 3666-3670, 1975.

14. Gaur U and Aggarwal BB: Regulation of proliferation, survival and apoptosis by members of the TNF superfamily. Biochem Pharmacol 66: 1403-1408, 2003.

15. Tavangar SM, Shariftabrizi A and Soroush AR: Her-2/neu overexpression correlates with more advanced disease in Iranian colorectal cancer patients. Med Sci Monit 11: CR123-CR126, 2005.

16. Kapitanovic S, Radosevic S, Kapitanovic M, Andelinovic S, Ferencic Z, Tavassoli M, Primorac D, Sonicki Z, Spaventi S, Pavelic K and Spaventi R: The expression of p185(HER-2/neu) correlates with the stage of disease and survival in colorectal cancer. Gastroenterology 112: 1103-1113, 1997.

17. Li JW, Chuang TC, Yang AH, Hsu CK and Kao MC: Clinicopathological relevance of HER2/neu and a related gene-protein cubic regression correlation in colorectal adenocarcinomas in Taiwan. Int J Oncol 26: 933-943, 2005.

18. Chen HC, Hsieh WT, Chang WC and Chung JG: Aloe-emodin induced in vitro G2/M arrest of cell cycle in human promyelocytic leukemia HL-60 cells. Food Chem Toxicol 42: 1251-1257, 2004. 
19. Bradford MM: A rapid and sensitive method for the quantitation of microgram quantities of protein utilizing the principle of protein-dye binding. Anal Biochem 72: 248-254, 1976.

20. Su CC, Chen GW, Kang JC and Chan MH: Growth inhibition and apoptosis induction by tanshinone IIA in human colon adenocarcinoma cells. Planta Med, 2008, Jul 11 (Epub ahead of print).

21. Cohen GM: Caspases: the executioners of apoptosis. Biochem J 326: 1-16, 1997.
22. Hu YP, Venkateswarlu S, Sergina N, Howell G, St. Clair P, Humphrey LE, Li W, Hauser J, Zborowska E, Willson JK and Brattain MG: Reorganization of ErbB family and cell survival signaling after knock-down of ErbB2 in colon cancer cells. J Biol Chem 280: 27383-27392, 2005.

23. Wakeling AE, Guy SP, Woodburn JR, Ashton SE, Curry BJ, Barker AJ and Gibson KH: ZD1839 (Iressa): an orally active inhibitor of epidermal growth factor signaling with potential for cancer therapy. Cancer Res 62: 5749-5754, 2002. 